\title{
EPISTEMOLOGI FIQH KEMADZHABAN NU
}

\author{
Nashrun Jauhari, Ratna Suraiya \\ Institut Pesantren KH. Abdul Chalim Mojokerto \\ Institut Agama Islam Al-Khoziny Sidoarjo \\ Email: nashrunjauhari25@gmail.com ; ratnasuraiya88@gmail.com
}

\begin{abstract}
The Nahdlatul Ulama (NU) is quite well known as a religious community organization that maintains the tradition of fiqh with civilization. Because since its inception it has made the ASWAJA ideology the basis of theology, adhering to one of the four schools; Hanafi, Maliki, Shafi'i, and Hambali as guidelines in the practice of Islamic law. The tradition of this diversity often gets criticism and even blasphemy from various parties regarding its validity to live a religious life. Because $N U$ is considered to not have a strong methodology thinking ground, especially in the field of Islamic law. This study examines the epistemology of the $N U$ 's kemadzhaban fiq both regarding the meaning of $N U$ about fiqh bermadhab and the methodology of fiqh based on madzhab. The results of this study found that, the tradition of bermadzhab fiqh had started since the time of the Companions of the Prophet, according to $N U$ according to $N U$ not only taqli d blind to the statements of the texts of the yellow book but to follow and develop the concept of thinking of the priests in establishing the law, and the system the establishment of the NU formulation law really has a strong scientific footing.
\end{abstract}

Keywords: Fiqh, Madhab and NU

\begin{abstract}
ABSTRAK
Nahdlatul Ulama (NU) cukup dikenal sebagai organisasi kemasyarakatan keagamaan yang mempertahankan tradisi fiqh bermadzhab. Karena sejak awal berdirinya telah menjadikan faham ASWAJA sebagai basis teologi, menganut salah-satu dari empat madzhab; Hanafi, Maliki, Syafi'i, dan Hambali sebagai pedoman dalam pengamalan hukum Islam. Tradisi kemadzhaban ini seringkali mendapatkan kritik bahkan hujatan dari berbagai pihak mengenai keabsahannya untuk menjalani kehidupan beragama. Karena NU dianggap tidak memiliki pijakan metodologi berpikir yang kuat khususnya di bidang kemadzhaban hukum Islam. Penelitian ini mengkaji epistemologi fiqh kemadzhaban NU baik menyangkut pemaknaan NU tentang bermadzhab fiqh maupun format metodologi fiqh berbasis madzhab. Adapun hasil dari penelitian ini menemukan bahwa, tradisi bermadzhab fiqh sudah dimulai sejak masa Sahabat Nabi, bermadzhab menurut NU bukan semata taqlid buta terhadap pernyataan teks-teks kitab kuning tetapi mengikuti dan mengembangkan konsep berpikir imam-imam madzhab dalam menetapkan hukum, dan sistem penetapan hukum rumusan NU benar-benar memiliki pijakan ilmiah yang kuat.
\end{abstract}

Kata Kunci: Fiqh, Madzhab dan NU

\section{LATAR BELAKANG}

Dalam perjalanan sejarah Islam, tidak terpungkiri terjadinya polarisasi masyarakat muslim dalam bentuknya sebagai organisasi, komunitas atau golongan dengan orientasi gerakan, pemikiran dan ideologi yang berbeda-beda. Pada bidang 
hukum Islam polarisasi telah terjadi sejak akhir periode Sahabat dengan munculnya madzhab Ahl al-Hadith dan madzhab Ahl al-Ra'yi, hingga melahirkan madzhabmadzhab fiqh di masa berikutnya. Dari setiap madzhab atau aliran kemudian membangun pola keislaman masing-masing, bukan hanya pada praktek peribadatan tetapi juga pada prinsip-prinsip penetapan masalah hukum.

Polarisasi semisal ini juga terjadi pada masyarakat muslim di tanah air baik yang berbentuk organisasi, komunitas atau golongan. Nahdlatul Ulama (NU) adalah salah satu organisasi kemasyarakat keagamaan di Indonesia yang secara tegas system kemadzhaban dalam pengamalan ajaran-ajaran keislaman. NU sejak awal berdirinya telah menjadikan faham Ahl al-Sunnah wa al-Jamā 'ah (ASWAJA) sebagai basis teologi (dasar berakidah) dan menganut salah-satu dari empat madzhab; Hanafi, Maliki, Syafi'i, dan Hambali sebagai pedoman dalam pengamalan hukum Islam. ${ }^{1}$ Sikap ini secara konsekuen ditindak-lanjuti dengan upaya pengambilan hukum Islam dari referensi berupa literatur-literatur hukum Islam klasik dan sekligus mengikuti pemikiran fiqh yang dikembangkan oleh para ulama madzhab. Pemikiran fiqh berbasis madzhab hingga saat ini terus dikembangkan khususnya melalui sebuah forum yang dinamai Lajnah Bahtsul Masa'il.

Studi hukum Islam dalam perkembangannya saat ini sudah banyak mengkaji pemikiran hukum dari madzhab-madzhab fiqh klasik, dan bahkan dari lembagalembaga fatwa yang ada di sejumlah negara. Sementara itu, kajian hukum Islam yang secara khusus meneliti metodologi figh kemadzhaban NU masih terbilang sedikit, apalagi untuk menimbang kelayakannya sebagai sebuah metode penetapan hukum Islam dari sudut pandang epistemologi. Tulisan ini dimaksudkan untuk meneliti langkah-langkah metode penetapan hukum Islam yang ditempuh oleh NU melalui lembaga fatwanya, dan sekaligus untuk mengetahui pemahaman kemadzhaban yang dianut.

\section{KEMADZHABAN DALAM KHAZANAH PEMIKIRAN HUKUM ISLAM}

Sebagaimana tercatat dalam sejarah, kemadzhaban (tamadzhub) atau praktek untuk mengikuti pendapat hukum dari seorang imam atau mengikuti cara berpikirnya

\footnotetext{
${ }^{1}$ Sahal Mahfudz, "Bahtsul Masa'il dan Istinbath Hukum NU” dalam Ahkam al-Fuqaha', (Surabaya : LTNU Jawa Timur, cet. II, 2005), h. ix.
} 
telah muncul di tengah kehidupan masyarakat Arab-Islam sejak sepeninggal Nabi pada periode Sahabat. Sebagaimana kita melihat tata kehidupan masyarakat saat ini yang mengenal adanya strata sosial dan taraf keilmuan. Demikian pula di zaman Sahabat, tidak semua dari mereka mempunyai potensi keilmuan yang sama dalam memahami Islam. Sebagian besar adalah kaum awam, dan hanya sebagian kecil dari mereka yang memahami tentang hukum Islam dan ahli fatwa, di antaranya adalah: Sayyidah 'A'shah, 'Umar ibn Khaṭ̂̄āb, Ibnu 'Umar, Abū Hurayrah, Ibnu 'Abbās, Zayd ibn Thābit, Mu'ādh ibn Jabal, dan 'Alì ibn Abì Ṭālib. ${ }^{2}$

Pada akhir periode Sahabat setelah tahun 40 Hijriyyah, dakwah Islam mulai tersebar ke beberapa wilayah di Jazirah Arab. Para Sahabat pun tidak lagi berdomisili di satu tempat tetapi menyebar ke beberapa wilayah tersebut seperti Iraq, Mesir dan Yaman. Hal ini mengakibatkan munculnya dua madzhab besar dalam pemikiran hukum Islam di kalangan Sahabat. Madzhab pertama dikenal sebagai "madzhab ahl al-Hadith" yang memandang bahwa Islam sebagai agama yang dogmatis dengan rumusan hokum bersifat tekstual, dan sebagai tokohnya adalah sebagian besar Sahabat yang masih tinggal di wilayah Hijāz (Makkah-Madinah). Sedangkan madzhab kedua dikenal sebagai "madzhab ahl al-Ra'yi”. Madzhab ini memandang bahwa Islam adalah agama yang bersifat rasional dengan rumusan hukum yang bersifat kontekstual, sebagai tokohnya adalah Ibn Mas'ūd dan 'Alì ibn Abì Ṭālib yang keduanya menetap di wilayah Iraq.

Para Sahabat yang ahli fatwa hukum Islam mempunyai murid-murid yang dikenal dengan sebutan golongan Täbi ‘in. Dari madzhab ahl al-Ra’yi melahirkan Shuraỵ̣ ibn Ḥārith (w. 78 H.), 'Alqamah ibn Qays (w. 62 H.), Masrūq ibn al-Ajdā' (w. 63 H.), Aswad ibn Yazīd (w. 95 H.) dan pada akhirnya diturunkan kepada Ibrāhīm alNakh`i (w. 85 H.) dan Hammād ibn Abi Sulaymān (w. 120 H.), yang keduanya merupakan guru dari Abū Hanīifah al-Nu'mān ibn Thābit (w. 150 H.) yang kemudian dinobatkan sebagai imam madzhab Ḥanafiyyah. Sedangkan dari madzhab ahl al-Hadith melahirkan enam orang ahli fiqh yang terkenal dengan julukan Fuqahā' al-Sittah, yang

\footnotetext{
${ }^{2}$ Mannā' Khalì al-Qațāan, Tārikh al-Tashrī' al-Islāmīi, (Riyad: Maktabah al-Ma 'ārif, 1992), h. 90. Bandingkan- Muhammad al-Khuḍari Bik, Tàrīkh al-Tashrī' al-Islāmī, (Beirut: Dār al-Fikr, cet. 8, 1967), h. 107-dst.
} 
pada akhirnya malahirkan seorang murid yang menjadi imam madzhab Mālikì, ia bernama Mālik ibn Anas (w. 179 H.), ${ }^{3}$

Pada abad ke-2 inilah muncul gelombang besar yang menghembuskan doktrin kemadzhaban untuk masa-masa berikutnya. Dan dari kedua madzhab tersebut —ahl alHadith dan ahl al-Ra'yi- mampu menghadirkan sosok mujtahid moderat bernama Muhammad ibn Idrīis al-Shāfíi (w. 204 H.) yaitu imam madzhab Shāfíiyyah. Sedangkan madzhab fiqh yang terakhir yaitu madzhab Hanbali dengan imam madzhabnya yang bernama Ahmad ibn Ḥanbal, beliau adalah salah satu murid dari imam al-Shāfi ‘̄.

Di masa kehidupan imam mujtahid empat (Abū Hanīfah, Mālik, al-Shāfi ‘َi dan Ibnu Hanbal) telah mampu menyuguhkan fatwa-fatwa hukum Islam ke dalam wacana keilmuan yang sistematik dan bahkan terkodifikasi dalam kitab-kitab karya mereka. Lebih dari itu, wacana keilmuan hukum Islam mereka lengkapi dengan landasanlandasan metodologi dalam melakukan ijtihad. Oleh karena itu, para ahli ussūl menyebut imam mujtahid empat sebagai "mujtahid mustaqil" karena keberhasilan mereka secara mandiri dalam merumuskan tata hukum Islam (fiqh) dan perangkatperangkat metodologi untuk mengeluarkan hukum dari sumber-sumbernya (ușūl alFiqh). ${ }^{4}$

Praktek kemadzhaban semakin tumbuh subur di tengah kehidupan kaum muslimin sepeninggal para mujtahid empat. Praktek kemadzhaban bahkan mentradisi dalam kehidupan keagamaan kaum muslimin, utamanya pada abad keempat hingga tumbangnya kedaulatan Baghdad tahun 656 Hijriyah. ${ }^{5}$

Praktek kemadzhaban kaum muslimin juga dilator-belakangi oleh gerakan kodifikasi atas perkembangan hukum Islam yang telah diterapkan selama tiga abad berturut-turut ke dalam bentuk disiplin ilmu fiqh dan usül al-Fiqh sehingga muncul suatu anggapan bahwa terma ijtihad telah final. Demikian halnya sikap kefanatikan terhadap madzhab tertentu menurut jalur intelektual yang diterima dari generasi ke

\footnotetext{
3 Aḥmad Amīn, Duḥā al-Islām, jilid 2, (Kairo: al-Hay'ah al-Mișriyyah al-'Ammah li al-Kitāb, 2003), h. 180 dan 208. Bandingkan- Muhammad Abū Zahrah, Tārīkh al-Madhāhib al-Islāmiyyah, (Kairo: Dār alFikr al-'Arabi, 1996), h. 265-dst.

${ }^{4}$ Muhammad Abū Zahrah, Usūul al-Fiqh, (Kairo: Dār al-Fikr al-'Arabī, 1996), h. 347

${ }^{5}$ Ahmad Amīn, Zuhr al-Isläm, jilid 3, (Beirut: Dār al-Kutub al-'Ilmiyyah, 2004), h. 44. Muhammad 'Ali al-Says, Tärikh al-Fiqh al-Islämī, (Beirut: Dār al-Fikr, cet. II, 2007), h. 187.
} 
generasi, dan bahkan menjadi terapan prundangan konstitusional dari kerajaan-kerajaan Arab-Islam. ${ }^{6}$

Semangat kreatif para ulama hanya diwujudkan dengan memberikan penjelasan dan pengembangan isi kitab (shaarh) dari kitab-kitab induk kemadzhaban, meringkas dan memadatkan keterangan kitab (mukhtasar), memberikan anorasi (hāshiyyah) terhadap kalimat-kalimat yang sukar dipahami, dan/atau menghadirkan alur pemikiran baru tetapi masih berjalan di atas rel-rel madzhab. Dari kreatifitas yang terkesan jalan di tempat tersebut, bukan berarti mereka bersikap fanatik buta terhadap gejolak pemikiran madzhab yang sedemikian dasyat. Para ulama tetap membuka mata dan mengfokuskan perhatian nya untuk merinci sedetail mungkin lika-liku penggalian hukum dan indikasi-indikasinya (Taḥiil al-Aḥkām) dari produk-produk ijtihad lepas landas yang dilakukan para mujtahid besar, pengkoreksian riwayat dari pendapatpendapat mereka (tarjị̣ al-Aqwāl), dan upaya pelestarian intelektual madzhab (Intishar al-Madzhab) ke dalam bentuk satuan-satuan normatif agar dapat menjadi batu loncatan terlahirnya mujtahid-mujtahid muda di setiap masa.

Namun pasalnya tradisi tersebut mengakibatkan pada degradasi berpikir bagi kaum muslimin yang mengarah kepada sikap fanatik buta kepada salah satu madzhab. Akhirnya berhujung pada munculnya klaim madzhabnya adalah yang paling benar dan yang lain itu salah bahkan sesat. Aksi-aksi anarkis dari para penganut madzhab yang terjadi di masjid al-Umawi di kota Damaskus menjadi pengalaman pahit sejarah.

Dengan melihat keterpurukan itu yang semakin merunyam, menuntut para ahli fiqh masa belakangan untuk melakukan upaya "harmonisasi antar madzhab" (Taqrïb bayn al-Madhāhib). Menurut para sejarawan, upaya harmonisasi antar madzhab ini telah dimulai semenjak abad ketuju Hijriyah selepas tumbangnya Baghdad. Usssaha semisal ini bukan dimaksudkan untuk membabat habis atau melebur madzhabmadzhab dengan ideologi pemikiran yang berbeda ke dalam satu pola pikir yang sejalan. Melainkan untuk medialogkan antar-madzhab melalui studi komperatif ilmiah dan dengan menimbang skala preoritas sesuai kondisi social-zaman. ${ }^{7}$ Sebagaimana kini yang dapat kita lihat wujud terapannya pada hukum perdata Kuwait dan Mesir dengan

\footnotetext{
${ }^{6}$ Muhammad Tājā, al-Madhāhib al-Fiqhiyyah wa al-Ta'ạssub al-Madhhabī, (Beirut: Dār Ibn Qutaybah, cet. I, 2004), h. 166-168

${ }^{7}$ Muhammad 'ATì al-Says, Tārīkh al-Fiqh al-Islāmīi, h. 212.
} 
madzhab Hanafi yang dipandang punya skala preoritas zaman, hukum pidana Mesir hasil pereduksian hukum pidana Prancis dengan madzhab Maliki, dan hukum rumahtangga dengan kompilasinya bahkan lebih dari madzhab empat.

Terlepas dari sikap fanatik para pengikut madzhab kepada imam madzhabnya. Praktek kemadzhaban pada dasarnya merupakan upaya untuk melandaskan pengamalan keagamaan menurut tuntunan syariat. Sedangkan untuk memahami tuntunan syariat tersebut membutuhkan serangkaian keilmuan yang mustahil dibebankan kepada semua umat Islam. Suatu hal yang menjadi keniscayaan yaitu bagi mereka yang awam butuh untuk mengikuti petunjuk dari mereka yang alim, sedangkan bagi mereka yang alim butuh mengikuti petunjuk dari mereka yang lebih alim. Atas dasar itu, dalam rangka menjaga keabsahan dalam memahami ajaran keislaman maka dibutuhkan acuan dalam bersikap dan berpikir kepada pihak-pihak yang telah teruji dan terpercaya atas potensi keilmuannya.

\section{KEMADZHABAN MENURUT NU}

Hal penting untuk diketahui sebelum berbicara menganai kemadzhaban (tamadhhub) menurut NU adalah penjelasan tentang terminologi ijtihād dan apa saja yang menjadi kreteria seseorang dapat disebut sebagai mujtahid. Dalam wacana pemikiran hukum Islam berkembang dua macam pemaknaan ijtihād: Pertama, memaknai ijtihād sebagai upaya keras seorang ahli hukum Islam dalam mengeluarkan hukum-hukum 'amaliyyah dari sumber-sumbernya secara terperinci. Sedangkan yang kedua, memaknai ijtihād sebagai upaya keras seorang ahli hukum Islam baik dalam mengeluarkan hukum-hukum dari sumber-sumbernya maupun dalam mengimplementasi hukum-hukum pada tataran praktis. ${ }^{8}$

Pemaknaan ijtihād yang pertama lebih tertuju pada pelaksanaan ijtihād mutlak secara sempurna yang dipraktekkan oleh imam mujtahid empat. Menurut pendapat ini, seseorang dapat disebut sebagai seorang mujtahid apabila telah memenuhi semua persyaratan ijtihād dan mampu melakukan ijtihăd pada semua persoalan hukum. Sedangkan bagi seseorang yang belum memenuhi semua persyaratan ijtihād walaupun memiliki potensi untuk melakukan penggalian hukum tetapi belum sampai pada derajat

\footnotetext{
${ }^{8}$ Muhammad Abū Zahrah, Ușül al-Fiqh, h. 379.
} 
mujtahid mutlak, maka tetap dihukumi sebagai seorang muqallid atau pengikut madzhab. Sebagaimana al-Nawawī (w. 676 H.) dalam al-Majmū' mengklasifikasi derajat mufti (ahli fatwa) hanya ke dalam dua katagori: (1) mufti mustaqil, yaitu ahli fatwa yang mandiri dalam menggali hukum atau mujtahid mutlak; dan (2) mufti ghayr mustaqil, yaitu ahli fatwa yang keilmuannya belum sampai pada derajat mufti mustaqil. Katagori kedua ini masih digolongkan sebagai seorang muqallid atau pengikut madzhab. Adapun yang termasuk katagori bukan mujtahid adalah:

1. Seseorang yang tidak mengikuti baik dalam hasil fatwa maupun dalilnya, tetapi melakukan penggalian hukum dengan mengikuti pola berpikir (sulūk al-Fikr) imam madzhab, derajat ini disebut muftī muntasab fi madhhab.

2. Seseorang yang melakukan penggalian hukum dengan mengikuti metode ijtihād hasil rumusan imam madzhab, derajat ini disebut mufti muqayyad fi al-Madhhab.

3. Seseorang yang belum mampu melakukan penggalian hukum secara mandiri tetapi memahami secara detail cara penggalian hukum, landasan-landasan dalil dan metode ijtihàd yang dilaalui oleh imam madzhab, derajat ini disebut hăfíz al-Madhhab.

4. Seseorang yang memahami secara mendetail terhadap fatwa-fatwa madzhab tetapi belum secara mendalam mengetahui dalil-dalil yang menjadi landasannya, namun derajat ini mampu membedakan antara validitas fatwa dalam madzhabnya. ${ }^{9}$

Sedangkan pemaknaan ijtihăd yang kedua yaitu sebagai upaya penggalian hukum dan implementasi hukum, merupakan pemaknaan yang banyak terwacana pada kitab-kitab usuul al-Fiqh karya ulama kontemporer. Tujuannya adalah untuk membangkitkan kembali semangat ijtihäd dengan lahirnya mujtahid-mujtahid muda agar kondisi umat Islam tidak terlalu lama terkungkung pada fanatisme madzhab. Pada pemaknaan kedua ini tingkatan mujtahid terbagi menjadi lima derajat yang semuanya menggunakan sebutan mujtahid, yaitu: (1) mujtahid mutlaq, (2) mujtahid muntasab, (3) mujtahid madhhab, (4) mujtahid murajjịh, dan (5) mujtahid mụăfiz.

\footnotetext{
${ }^{9}$ Abū Zakariyā Yahyā ibn Sharaf al-Nawawī, al-Majmū' Sharh al-Muhadhdhab, jilid 1, (Kairo: Matba'ah al-Muniriyyah, t.th.), h. 75-dst.
} 
Adapun pandangan umum yang dikenal ulama NU tentang pemaknaan ijtihād dan tingkatan-tingkatan mujtahid, NU lebih memilih pendapat pertama yang hanya membedakan dua golongan; mujtahid dan muqallid. Menurut ulama NU, mujtahid sepenuhnya hanyalah mujtahid mutlak atau mujtahid mustaqil. Dengan demikian di bawah mujtahid mutlak adalah tergolong muqallid. ${ }^{10}$ Pengertian inilah yang ditempuh oleh ulama NU dalam bab prinsip pemikiran hukumnya tidak menyatakan diri sebagai golongan mujtahid, akan tetapi menyatakan diri sebagai golongan muqallid.

Kecondongan ulama NU kepada pendapat pertama karena sikap fanatik kepada ketokohan al-Nawawi, namun pendapat tersebut juga merupakan pandangan mayoritas ulama. $^{11}$ Berkenaan dengan hal ini al-Nawawi dalam kitab al-Rawdah mengelompokkan ulama menjadi dua; pertama, ulama awam, dan kedua, ulama yang sampai pada tingkatan mujtahid yang tidak boleh taqlid kepada ulama lain. Selanjutnya adalah mereka yang berada di tengah-tengah antara keduanya, yakni tidak sampai kepada tingkatan mujtahid tetapi mereka mengetahui metodologi yang diterapkan imamnya. Dalam istilah beliau, mereka yang berada di tengah itu disebut muqallid. ${ }^{12}$ Dan, juga tiada beda antara taqlid danittiba ${ }^{-}$, keduanya memiliki makna yang sama dan tidak berbeda menurut asal bahasanya, yaitu "mengikuti madzhab". Sebagaimana al-Quran yang selalu menyamakan antara kedua kata tersebut, firman Allah dalam surat al-Baqarah ayat $166-167 .^{13}$

Pandangan al-Nawawi untuk mengkatagorikan ulama yang berada pada posisi tengah di atas sebagai pihak yang boleh pengikut madzhab merupakan pendapat jumhur ahli ushul dari kkkelompok Aswaja. ${ }^{14}$ Dan selanjutnya dipegangi oleh ulama NU sehingga memposisikan diri sebagai kaum pengikut madzhab. ${ }^{15}$ Sedangkan dalam

\footnotetext{
${ }^{10}$ Khotib Sholeh, KH., Menyoal Efektivitas Bahtsul Masa'il (dalam- Kritik Nalar Fikih NU), (Jakarta: PT. LAKPESDAM, cet. I, 2002), h. 220

11 Tajuddin Ibnu Subuki, Jam' al-Jawami', jilid 3, Maktabah Musthafa Bab al-Halabi, Kairo, 1937, hal. 397 dan Abu Hamid al-Ghazali, al-Mustashfa (tahqiq; Muhammad Abdussalam Abdussyafi), Dar alKutub al-Ilmiyyah, Beirut, 2000, hal. 367

12 Jalaluddin al-Suyuthi, al-Rad 'ala Man Akhlada ila al-Ardl wa Jahla anna al-Ijtihad fi Kulli 'Ashrin Fardlun, Mu'assasah Syabab al-Jami'ah, Iskandaria, 1985, hal. 164

${ }^{13}$ M. Sa'id Ramadlan al-Bouthi, Dr., al-Lamadzhabiyyah, Dar al-Farabi, cet. V, Beirut, 2009, hal. 83

14 Jamaluddin al-Asnawi, Nihayah al-Suul ma'a Syarah al-Badakhsyi, jilid 3, hal. 291. Saifuddin alAmidi, al-Ihkam fi Ushul al-Ahkam, jilid 3, Maktabah Misykat, hal. 170, Ibnu Abdussyakur, Musalam al-Tsubut, jilid 2, Maktabah Misykat, hal. 351

15 Imam Yahya, "Fikih Sosial NU dari Tradisionalis menuju Kontekstualis" dalam- Kritik Nalar Fikih $N U$, (Jakarta: PT. LAKPESDAM, 2002), h. 53
} 
perspektif yang lain, dari sebagian kalangan Mu'tazilah Baghdad, menyatakan ulama awam dan ulama tengah tersebut tidak boleh bertaqlid tetapi harus berijtihad dengan mengamati dalil sampai pada batas kemampuannya. ${ }^{16}$

KH. Ahmad Shidiq dalam bukunya Khitthoh Nahdliyyah mengemukakan pendapatnya bahwa persoalan taqlid tidak bisa lepas dari kecerdasan manusia, derajat kecerdasan manusia memang berbeda-beda, dari yang kelewat dungu sampai yang terlalu pinter. Karena perbedaan itu, maka berlakulah proses pen-taqlid-an dalam pemahaman ajaran Islam. Aktualisasi prinsip taqlid dalam pemikiran buku itu oleh para kyai NU terapresiasi dalam kutipan berikut :

"Meskipun sudah mahir, sudah hafal puluhan hadits dan tahu persis kelemahan dan kekuatan dalil-dalil yang dipergunakannya, bukan berarti sudah lepas dari tingkatan taqlid. Sebab persyaratan yang diperlukan bagi orang tidak mau menerima predikat taqlid tidaklah sederhana. Karena itu, Nahdlatul Ulama tetap mendidik warganya untuk tidak bersikap seperti orang yang sudah mampu berijtihad sendiri". ${ }^{17}$

Dengan demikian, persoalan taqlid bagi NU bukan lagi mengikuti, mengekor, atau membuta-tuli, melainkan persoalan "manusia", bukan hanya manusia yang ada di dalam NUmelainkan manusia seluruhnya.

\section{METODE NU DALAM BERMADZHAB FIQH}

Nahdlatul Ulama (NU), sebagai organisasi kemasyarakatan yang sekaligus gerakan keagamaan Islam, sejak awal berdirinya telah menjadikan paham Ahl alSunnah wa al-Jamā'ah sebagai basis teologi (dasar akidah) dan menganut salah-satu dari empat madzhab; Hanaf̣i, Mālikì, Shāfíc ‘, dan Hanbali sebagai pedoman dalam bidang hukum Islam. ${ }^{18}$ Sikap ini secara konsekuen ditindak-lanjuti dengan upaya pengambilan hukum Islam dari referensi berupa kitab-kitab fiqh dan sekligus mengikuti pemikiran fiqh yang dikembangkan oleh para ulama madzhab. Untuk

\footnotetext{
${ }^{16}$ Wahbah Zuhaili, , Ushul al-Fiqh al-Islamiy., jilid 2, Dar al-Fikr, cet. III, Beirut-Damaskus, 2005, hal. 411

${ }^{17}$ Ahmad Shidiq, Khitthoh Nahdliyyah, PBNU, Jakarta, TT., hal. 40

${ }^{18}$ Sahal Mahfudz, Bahtsul Masa'il dan Istinbath Hukum NU(dalam pengantar buku; Ahkam al-Fuqaha), LTNU Jawa Timur, cet. II, Surabaya, 2005, h. ix
} 
memutuskan segala perkara hukum, NU mempunyai sebuah forum yang disebut Lajnah Bahtsul Masa'il Nahdlatul Ulama (LBMNU). Forum ini bertugas mengambil keputusan tentang ajaran Islam baik yang berkaitan dengan masalah hukum, maupun masalah akidah dan bahkan masalah tasawuf.

Istilah istinbăt hukum tidak banyak dikenal di kalangan ulama NU. Bagi mereka terma itu lebih dikonotasikan pada penggalian hukum dari sumber-sumber primer; al-Quran dan Sunnah yang wilayah garapan para mujtahid mutlak, yang menurut ulama NU sangat berat untuk dilakukan. Maka, sebagai gantinya adalah ittifäq al-Hukm (kesepakatan hukum).

NU lebih cenderung menyandarkan upaya penggalian hukum kepada kaidahkaidah fịh (al-Qawā'id al-Fiqhiyyah) dan kaidah-kaidah usūil (al-Qawā‘id alUsūiliyyah). ${ }^{19}$ Dua jenis kaidah tersebut pada dasarnya sudah sangat mewakili sebagai pijakan penetapan hukum Islam. Karena, kaidah fiqhiyyah merupakan hasil penelitian induktif dari hukum-hukum particular-praktis, sedangkan kaidah usūliyyah merupakan sarana untuk memahami makna-makna hukum dari dalil-dalil tekstual dan rasional. ${ }^{20}$ Keduanya memiliki fungsi yang cukup urgen dalam melangsungkan penggalian hukum, agar mendapatkan pemahaman yang tepat sasaran, dan sebagai langkah awal yang lebih selamat dari kesalahan dalam melangsungkan istinbath hukum.

Dengan demikian, produk hukum yang dihasilkan NU merupakan hasil ijtihad ulama atas dasar teks-teks al-Quran dan Sunnah yang sesuai dengan prinsip-prinsip mujtahid terdulu. Hal ini sesuai dengan isi dari Sistem Penggalian Keputusan Hukum (SPKH) NU yang menyatakan: "Nahdlatul Ulama mendasarkan faham keagamaannya kepada sumber al-Quran, as-Sunnah, al-Ijma' dan al-Qiyas".

Sementara itu dalam sistem bermadzhab yang dianut NU dalam prakteknya tidak selalu merujuk kepada empat madzhab yang diakuinya. Tetapi, setiap put usan hukum yang diambilnya lebih banyak — dengan tidak mengatakan semuanyamerujuk kepada madzhab Syafi'i. sedangkan dalam merujuk madzhab Syafi'i-pun, tidak menukil langsung dari kitab-kitab karya Imam al-Syafi'i, seperti; al-Umm, al-Risalah,

\footnotetext{
19 Imam Yahya, Akar Sejarah Bahtsul Masa'il (dalam; Kritik Nalar Fikih NU), (Jakarta: PT. LAKPESDAM, cet. I, 2002), h. 15

${ }^{20}$ Muhammad Abu Zahrah, Ushul al-Fiq, op. cit., hal. 12-13
} 
Jima' al-Ilm, Ahkam al-Qur'an, dan al-Musnad, melainkan merujuk kepada kitab-kitab fikih yang ditulis oleh ulama Syafi'iyah.

Cara ini ditempuh karena adanya pertimbangan antara lain dijelaskan oleh $\mathrm{KH}$. Ali Ma'shum, sebagai berikut:

"menurut hemat para kyai NU, 'ibārāt (pernyataan) kitab-kitab karya imam alShāfi ‘i tersebut seringkali masih terlalu mujmal sehingga memerlukan rincian dan penjelasan. Rincian dan penjelasan ini hanya dapat diberikan oleh para ulama madzhab Shāfi ‘̄i yang memang telah mengenal dengan baik metode istinbăt imam al-Shāfi ${ }^{\leftarrow}$. Di samping itu pula, pada umumnya di antara ulama

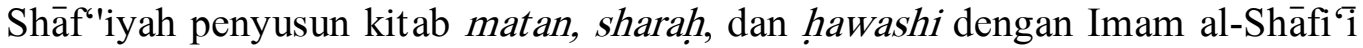
terdapat mata rantai tali keilmuan yang tidak terputus, yang dikenal dengan istilah isnād dalam menuntut ilmu". ${ }^{21}$

Dan dengan menyadari bahwa di kalangan ulama Syafi'iyah sendiri mustahil terdapat kesepakatan dalam semua masalah, maka ulama NU memberikan aturan dalam pengutipan 'ibārāt yang secara hirarkis adalah: (1) Pendapat yang terdapat kata sepakat antara al-Nawawi dan al-Rāfi $َ \bar{i}$. (2) Pendapat yang dipilih oleh Imam alNawawi saja. (3) pendapat yang dipilih oleh al-Rāfi ‘i saja. (4) Pendapat yang disokong oleh ulama terbanyak. (5) Pendapat ulama yang terpandai. (6) pendapat ulama yang paling wara $^{-} \cdot 22$

Dari penjelasan di atas, menunjukkan bahwa NU melalui lembaga fatwanya selalu konsisten menjawab semua persoalan hukum yang dihadapi dengan cara merujuk kitab-kitab madzhab empat, terutama madzhab Shāfi ‘ $\mathfrak{i}$. Dari satu sisi, model penetapan hukum ini tampak praktis dan mudah karena langsung merujuk kepada produk fatwa. Namun cara ini lebih selamat dan terhindar dari kesalahan-kesalahan daripada menggali hukum secara langsung dari al-Quran dan Sunnah yang membutuhkan keilmuan yang tinggi. Merujuk kepada kitab-kitab madzhab secara tidak langsung juga merujuk kepada al-Quran dan Sunnah. Karena seorang pengkaji akan ikut serta menjelajahi langkah-langkah analisis dari ulama-ulama madzhab yang menulis kitab-

\footnotetext{
${ }^{21}$ Dikutip oleh KH. Khotib Sholeh, Menyoal Efektifitas Bahtsul Masa'il, op. cit., hal. 237

${ }^{22}$ Ahkam al-Fuqaha', (Surabaya : LTNU Jawa Timur, cet. II, 2005), h. 3.

Bandingkan- 'Ali Jum'ah, al-Madkhal ila Dirasah al-Madzahib al-Fiqhiyyah, (Kairo:Dar al-Salam, cet. I, 2004), h. 49-50
} 
kitab tersebut. Untuk lebih jelas mengamati proses penetapan hukum melalui kitabkitab madzhab dan kesinambungannya dengan rujukan sumber-sumber hukum Islam dapat diamati pada skema berikut :

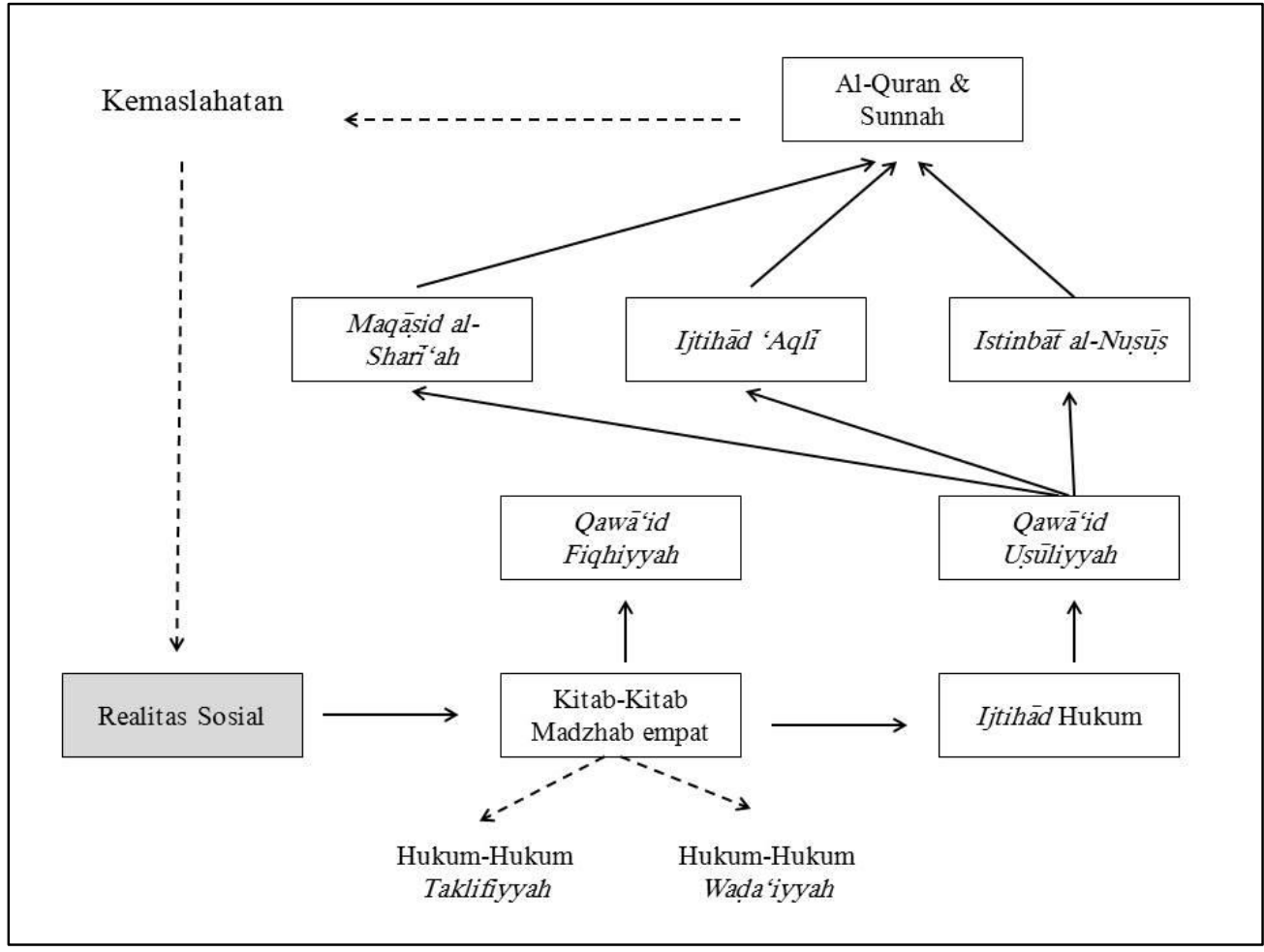

Seak Musyawarah Nasional (MUNAS) Alim Ulama di Lampung pada 16-20 Rajab 1412 H./21-25 Januari 1992, NU merevisi metode penetapan hukumnya. Musyawarah Nasional tersebut mengeluarkan keputusan berupa "Sistem Pengambilan Keputusan Hukum" (SPKH). Dalam keputusan tersebut NU memeiliki empat tahapan metodik, yaitu: ${ }^{23}$

\footnotetext{
${ }^{23}$ Sistem Pengambilan Keputusan Hukum" (SPKH) dalam MUNAS Alim Ulama NU di Lampung 1992 menyatakan: "Keputusan Bahtsul Masa'il di lingkungan NU dibuat dalam kerangka bermadzhab kepada salah satu madzhab empat yang disepakati dan mengutamakan bermadzhab secara qawlii. Oleh sebab itu, prosedur penjawaban masalah disusun dalam urutan sebagai berikut : (1) Dalam kasus ketika jawaban bisa dicukupi oleh 'ibārāt kitab dan di sana terdapat hanya satiu qawl, maka dipakailah qawl sebagaimana diterangkan dalam 'ibărăt tersebut. (2) Dalam kasus ketika jawaban bisa dicukupi oleh 'ibārāt kitab dan di sana terdapat lebih dari satu qawl, maka dilakukan taqrīr jamā̄ $\bar{i}$ untuk memilih satu qawl. (3) Dalam kasus tidak ada satu qawl sama sekali yang memberikan penyelesaian, maka dilakukan prosedur ilhạq al-Masā'il bi Nază 'irihā secara jamā $\bar{i}$ oleh para ahlinya. (4) Dalam kasus tidak ada satu qawl sama sekali dan tidak mungkin dilakukan ilhăq, maka bisa dilakukan istinbật jamā $\bar{i}$ dengan prosedur bermadzhab secara manhajī oleh para ahlinya."

Lihat- Ahkam al-Fuqaha',h. 470-471.
} 
1. Metode Qawli (tekstual) yang dipraktekkan dengan mencari suatu keterangan fatwa yang tertulis pada teks kitab klasik. Tahap ini ditetapkan ketika jawaban hanya ada satu pendapat hukum, maka langsung dipakai pendapat yang adal

2. Metode Taqrīr Jamāi $\bar{i}$, yaitu menetapkan hukum dengan bermusyawarah untuk mencari pernyataan hokum yang relevan. Metode ini dilakukan apabila dalam suatu masalah muncul dua pendapat, maka dilakukan kompromisasi dua pendapat tersebut bila memungkinkan, bila tidak dimungkinkan maka dipilih satu pendapat yang lebih kuat.

3. Metode Ilhăq al-Masā'il bi Nază'irihāa, yaitu dilakukan dengan menganalogikan kasus baru yang mucnul di masyarakat dengan kasus lama yang termaktub di dalam kitab madzhab. Metode ini ditempuh apabila metode tahap pertama dan kedua menjumpai jalan buntu.

4. Metode Istinbạt Manhajī, yaitu melakukan penggalian hukum dari sumbersumber hukum Islam secara langsung dengan mengikuti tahapan-tahapan metodologis dalam kaidah-kaidah fiqhiyyah dan kaidah-kaidah usūiliyyah. Metode ini ditempuh sebagai jalan terakhir dari ketiga langkah metode sebelumnya.

Dari empat prosedur penetapan hukum di atas, dapat dikatakan bahwa prosedur pertama dan kedua, yaitu metode qawli dan metode taqrír jama $\bar{i}$, pada hakekatnya memuat maksud yang sama. Kedua metode ini sama-sama dilakukan dalam praktek ijtihad kolektif oleh tim Bahtsul Masa'il NU. Praktek metode qawli adalah dilakukan dengan mengutip pernyataan teks kitab secara langsung. Pengutipan ini pastinya dilakukan setelah melalui proses dialog panjang untuk menentukan pernyataan teks mana dan dari kitab apa yang relevan untuk dipilih sebagai putusan hukum. Sebagaimana pula kinerja dari metode taqrír jamā $\bar{i}$ untuk mengkompromisasi atau memilih lebih dari satu pernyataan pendapat dari kitab madzhab.

Ditinjau dari segi kelayakannya sebagai sebuah metode penetapan hukumIslam, maka penerapan metode qawli dan taqrir jamāi di kalangan NU cukup layak untuk diakui, karena merupakan cara untuk mengimplementasi hukum Islam dari sebuah hasil ijtihad yang telah teruji keabsahannya dan relevansi kemaslahatannya. Menurut Abū 
Zahrah, sebagaimana telah disinggung sebelumnya, bahwa jtihād juga dapat diartinya sebagai upaya untuk mengimplementasi hukum Islam untuk dikeluarkan dalam bentuk fatwa. Sedangkan Yūsuf al-Qaraḍ̄āi mengistilahkan penerapan metode ini sebagai

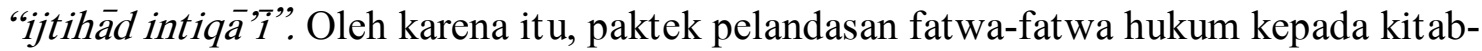
kitab fiqh kemadzhaban hingga saat ini tetap dipakai dan diberlakukan sebagai salah satu sistem penetapan hukum di sebagian besar lembaga fatwa seperti di Mesir, Kuwait, Suriya dan yang lainnya.

Adapun prosedur penetapan hukum yang ketiga, yaitu yang disebut metode ilhăq al-Masā'il bi nazāìrihā. Istilah metode ini tidak pernah kita jumpai dalam literatur-literatur usūl al-Fiqh, tetapi secara operasional hampir serupa dengan metode qiyās, yaitu menganalogikan kasus baru dengan kasus lama yang sudah pernah ada. Hanya saja dalam konsep qiyās mensyaratkan bahwa kasus lama yang menjadi sandaran hukum harus dinyatakan oleh nas al-Quan dan Sunnah. Sedangkan dalam konsep ilhāq kasus lama yang menjadi sandaran hukum dinyatakan oleh pernyataan fatwa-fatwa madzhab.

Banyak pihak menganggap NU mengada-ada dan kelayakannya ilhăq sebagai sebuah metode penetapan hukum patut dipertanyakan. Barangkali anggapan ini muncul bagi mereka yang hanya mengenal satu model dari sejumlah model qiyăs yang diperbincangkan oleh kalangan usüliyyūn. Kekayaan intelektual para Kyai NU cukup meluas dan mendalam tentang ussūl al-Fiqh sehingga mampu mengaktualisasi wacana klasik pada dunia modern. Al-GhazāTi dalam al-Mustasfá pernah mewacanakan salah satu model qiyās yang konon riwayatnya banyak digunakan oleh al-Shāfí 'í, yaitu jenis qiyās mașạ̣hī. Konsep qiyās jenis ini tidak mensyaratkan kasus lama (al-Assl) yang menjadi sandaran kasus baru (al-Far') harus termaktub pada literal ayat al-Quran dan Sunnah, tetapi boleh pada nilai kemaslahatan yang diamanatkan dari pernyataan ayat al-Quran dan Sunnah. ${ }^{24}$ Konsep qiyās jenis inilah yang kemudian diganti nama dengan istilah ilhaq, demi menjaga sikap rendah hati para Kyai NU agar tidak terkesan arogan melakukan qiyās seperti para mujtahid mutlak.

\footnotetext{
${ }^{24}$ Konsep qiyās mașlāhī juga dijadikan dalih al-Ghazāii dalam mengklarifikasi sikap al-Shāfi ${ }^{` i}$ yang menolak masāliḥ mursalah dan istịhsān tetapi menggantinya dengan konsep kemaslahatan yang dipandang lebih dekat dengan nas syariat, yaitu berupa qiyās mas̆lāhỉ . Abū Hāmid al-Ghazāî̀, al-

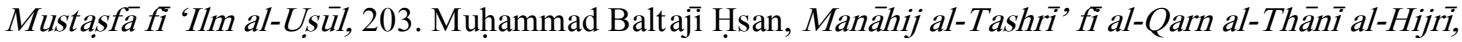
jilid 2, (Kairo: Dār al-Salām, 2004), h. 612.
} 
Sementara itu, untuk prosedur keempat berupa metode istinbăt manhaji kinerjanya tidak lain adalah mengacu kepada kaidah-kaidah ușūliyyah untuk menggali makna-makna hukum yang terkandung dalam al-Quran dan Sunnah. Metode istinbạt manhaji sering kali dilakukan untuk mencari solusi hukum pada masalah-masalah diniyyah mawdū'iyyah (tematik), seperti dalam masalah HAM, yang tidak lagi merujuk pada kitab-kitab klasik tetapi langsung kepada al-Quran dan Sunnah dengan mengikuti aturan main usül al-Fiqh. Metode yang terakhir inilah yang akan selalu menyegarkan pola pikir NU dalam berargumentasi fiqh. Sebab ụsūl al-Fiqh sendiri terus mengalami perkembangan hingga berevolusi ke dalam metode ijtihād berbasis maqāsid al-Sharī'ah.

\section{KESIMPULAN}

Berdasarkan data yang terdiskripsikan di atas dapat ditarik beberapa kesimpulan mengenai epistemologi fiqh kemadzhaban yang dianut oleh Nahdlatul Ulama.

Pertama: praktek kemadzhaban khususnya dalam bidang hukum Islam bukanlah satu-satunya tradisi yang dikembangkan oleh NU, tetapi menjadi sebuah tradisi yang sudah lama berkembang dan bahkan menjadi identitas keagamaan sejak masa Sahabat Nabi, Tabi'in, imam-imam mujtahid dan masa-masa setelahnya.

Kedua: kemadzhaban (tamadhhub) dalam bidang hukum Islam memiliki makna mengikuti ajaran dari para imam madzhab baik secara langsung dengan mengadopsi hasil-hasil fatwa mereka, maupun mengikuti konsep berpikir para imam madzhab dalam menetapkan fatwa-fatwa hukum Islam.

Ketiga: Fiqh kemadzhaban NU adalah mengikuti imam-imam mujtahid madzhab empat (Hanafī, Mālikī, Shāfi ‘i dan Hanbali). Sedangkan mengenai sistem pengambilan keputusan hukum yang berbasis madzhab ini mempunyai empat langkah metodik, yaitu: metode qaw $\bar{i}$, metode taqrir jamāi, metode ilhaq, dan metode istinbạt manhaji.

Keempat: dari empat langkah metode penetapan hukum yang digunakan NU semuanya mempunyai landasan ilmiah yang cukup kuat dan layak sebagai sebuah perangkat metodologi ijtihad, dengan rincian umum: (1) Metode qawli dan taqrir 
jamāis merupakan upaya mengimplementasi hukum Islam dalam bentuk fatwa. Hal ini diakui para ahli sebagai salah satu jenis metode ijtihad di era modern. (2) Metode ilhāq al-Masā'il bi Nazā'irihā bukanlah metode yang dirumuskan secara ngawur, tetapi merupakan bentuk aktualisasi dari konsep qiyās maslahi yang pernah diwacanakan alGhazāli. (3) Metode istinbạt manhajī tidak lain adalah konsepsi ụsūl al-Fiqh yang akan berkembang sebagai sebuah metodologi berpikir dalam bidang hukum Islam.

\section{DAFTAR PUSTAKA}

Muhammad Baltajì Ḥsan, Manāhij al-Tashrì' fī al-Qarn al-Thānī al-Hijrī, jilid 2, (Kairo: Dār al-Salām, 2004),

Abū Hāmid al-GhazāTi, al-Mustasfā fí 'Ilm al-Usūl, (Beirut: Dār al-Fikr, 2000)

'Ali Jum'ah, al-Madkhal ila Dirasah al-Madzahib al-Fiqhiyyah, (Kairo:Dar al-Salam, cet. I, 2004),

KH. Khotib Sholeh, Menyoal Efektifitas Bahtsul Masa'il, op. cit., hal. 237

Fatwa NU, Ahkam al-Fuqaha': Solusi Problematika Hukum Islam, (Surabaya : LTNU Jawa Timur, cet. II, 2005), h. 3.

Mannā‘ Khalil al-Qațāan, Tārikh al-Tashrī' al-Islāmī, (Riyad: Maktabah al-Ma 'ārif, 1992),

Muhammad al-Khựarīi Bik, Tărīkh al-Tashrī' al-Islāmī, (Beirut: Dār al-Fikr, cet. 8, 1967)

Aḥmad Amīn, Duhāa al-Islām, jilid 2, (Kairo: al-Hay'ah al-Miṣriyyah al-‘Ammah li alKitāb, 2003)

, Zuhr al-Islām, jilid 3, (Beirut: Dār al-Kutub al-'Ilmiyyah, 2004)

Muhammad Abū Zahrah, Tārikh al-Madhāhib al-Islāmiyyah, (Kairo: Dār al-Fikr al'Arabī, 1996).

Muhammad Abū Zahrah, Usùul al-Fiqh, (Kairo: Dār al-Fikr al-'Arabī, 1996)

Muhammad 'Ali al-Says, Tärỉkh al-Fiqh al-Islāmì, (Beirut: Dār al-Fikr, cet. II, 2007), h. 187.

Muhammad Tājā, al-Madhāhib al-Fiqhiyyah wa al-Ta'așsub al-Madhhabì, (Beirut: Dār Ibn Qutaybah, cet. I, 2004), 
Abū Zakariyā Yạ̣yā ibn Sharaf al-Nawawī, al-Majmū' Sharh al-Muhadhdhab, jilid 1, (Kairo: Matba'ah al-Munïriyyah, t.th.).

Khotib Sholeh, Menyoal Efektivitas Bahtsul Masa'il (dalam- Kritik Nalar Fikih NU), (Jakarta: PT. LAKPESDAM, cet. I, 2002)

Tajuddin Ibnu Subuki, Jam' al-Jawami', jilid 3, Maktabah Musthafa Bab al-Halabi, Kairo, 1937,

Abu Hamid al-Ghazali, al-Mustashfa (tahqiq; Muhammad Abdussalam Abdussyafi),

Dar al-Kutub al-Ilmiyyah, Beirut, 2000

Jalaluddin al-Suyuthi, al-Rad 'ala Man Akhlada ila al-Ardl wa Jahla anna al-Ijtihad fi Kulli 'Ashrin Fardlun, Mu'assasah Syabab al-Jami'ah, Iskandaria, 1985,

M. Sa'id Ramadlan al-Bouthi, Dr., al-Lamadzhabiyyah, Dar al-Farabi, cet. V, Beirut, 2009 ,

Jamaluddin al-Asnawi, Nihayah al-Suul ma'a Syarah al-Badakhsyi, jilid 3, hal. 291.

Saifuddin al-Amidi, al-Ihkam fi Ushul al-Ahkam, jilid 3, Maktabah Misykat, hal. 170,

Ibnu Abdussyakur, Musalam al-Tsubut, jilid 2, Maktabah Misykat, hal. 351

Imam Yahya, "Fikih Sosial NU dari Tradisionalis menuju Kontekstualis" dalam- Kritik

Nalar Fikih NU, (Jakarta: PT. LAKPESDAM, 2002), h. 53

Wahbah Zuhaili, , Ushul al-Fiqh al-Islamiy., jilid 2, Dar al-Fikr, cet. III, BeirutDamaskus, 2005

Ahmad Shidiq, Khitthoh Nahdliyyah, PBNU, Jakarta, TT., hal. 40

Sahal Mahfudz, Bahtsul Masa'il dan Istinbath Hukum NU (dalam pengantar buku; Ahkam al-Fuqaha), LTNU Jawa Timur, cet. II, Surabaya, 2005, 